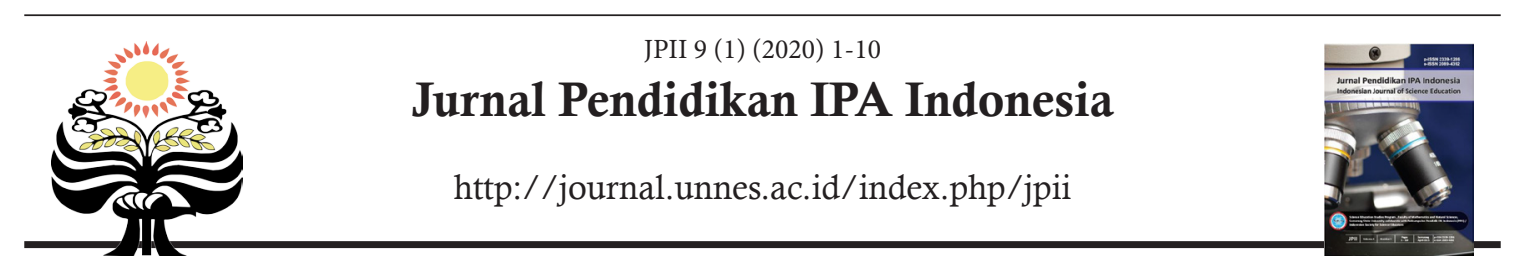

\title{
THE EFFECT OF 5E INQUIRY LEARNING MODEL ON THE SCIENCE ACHIEVEMENT IN THE LEARNING OF "MAGNET" AMONG YEAR 3 STUDENTS
}

\author{
E.T. Ong*1, B.L. Keok ${ }^{2}$, J. Yingprayoon ${ }^{3}$, C.K.S. Singh ${ }^{4}$, M.T. Borhan ${ }^{5}$, S.W. Tho ${ }^{6}$ \\ 1, 4, 5, 6 Universiti Pendidikan Sultan Idris, Malaysia \\ ${ }^{2}$ SK Sultan Idris II, Kuala Kangsar, Malaysia \\ ${ }^{3}$ Suan Sunandha Rajabhat University, Thailand
}

DOI: $10.15294 /$ jpii.v9i1.21330

Accepted: October $3^{\text {rd }} 2019$. Approved: March $5^{\text {th }} 2020$. Published: March $31^{\text {st }} 2020$

\begin{abstract}
The aim of this study is to determine the effect of the 5E Inquiry Learning Model as compared to the conventional method in enhancing third-grade students' science achievement using "magnet" as the learning material. A quasi-experimental pretest-posttest control group design was employed with the participation of 40 students from two intact Third-grade classes in a primary school in Kuala Kangsar. The experimental group was taught using the 5E Inquiry Learning Model which consists of 5 stages, namely Engagement, Exploration, Explanation, Expansion, \& Evaluation, while the control group was taught using the teacher-centered conventional method. The science achievement in the learning of "Magnet" was measured using a researcher-developed test consisting of 12 multiple-choice and 8 fill-in-the-blank items. The test has sufficient validity and KR-20 reliability. Analysis of the pretest data indicates that there was no statistically significant difference $(t=1.66, p>.05)$ in the pretest means between the experimental and control groups. Accordingly, an independent samples t-test was used to compare students' achievement in the posttest. The analysis of the posttest data indicates that the posttest mean in science achievement (16.05) among the group of students who had followed through the 5E Inquiry Learning Model is statistically significantly higher $(t=4.75, p<.001)$ than the corresponding mean $(13.15)$ among the group of students in the control group. Therefore, it can be concluded that the $5 \mathrm{E}$ Inquiry Learning Model enhances the learning of science in terms of achievement among the primary students.
\end{abstract}

(C) 2020 Science Education Study Program FMIPA UNNES Semarang

Keywords: Inquiry learning; 5E; Primary Science; magnet

\section{INTRODUCTION}

The 60:40 policy -- instituted in 1967 and implemented in 1970 , envisages that $60 \%$ of the Malaysian students will follow through the science stream, while the remainder $40 \%$ will uptake the arts and humanities subjects. The conceptualization and subsequent enactment of this 60:40 policy were due to the crucial needs of around 500,000 scientists and engineers by 2020 in Ma-

*Correspondence Address

E-mail: ong.engtek@fpm.upsi.edu.my laysia based on the projection of the National Council for Scientific Research and Development (Azian, 2015). However, the statistics as of 2014 indicate only about $45 \%$ of secondary students are taking the science stream which, according to Azian (2015), includes the technical-based subjects. Table 1 summarizes the statistics from the enrolment of Malaysian students at the Form 5 level for the Year 2018 by academic streams and gender (Educational Planning and Research Division, 2018). There is a total of 149,040 science-based students out of the overall 361,980 students, and this works out to be $41.17 \%$. 
Table 1. The Year 2018 Enrolment of Malaysian Students at Form 5 Level by Academic Streams and Gender

\begin{tabular}{lccc}
\hline & \multicolumn{3}{c}{ Year 2018 } \\
\cline { 2 - 4 } Form 5 (Upper Secondary) & Male & Female & Total \\
\hline Arts & 105,149 & 101,893 & 207,042 \\
Science & 33,754 & 50,032 & 83,786 \\
Religious & 2,184 & 3,714 & 5,898 \\
Vocational/Technology & 20,054 & 26,683 & 46,737 \\
Vocational & 9,958 & 6,211 & 16,169 \\
Technical & 1,201 & 1,147 & 2,348 \\
Total & 172,300 & 189,680 & 361,980 \\
\hline
\end{tabular}

The $41.17 \%$ of science-based Form 5 students recorded falls short of the aspired $60 \%$. The gloomy enrolment in science stream is further compounded by the Malaysia's unfavorable achievement in the Trends in Mathematics and Science Study (TIMSS) 2011 which indicates a marked degradation from the 21st ranking in TIMSS 2007 to 32nd ranking out of 63 countries in TIMSS 2011 (Martin et al., 2012). In TIMSS 2015, the ranking of Malaysia did improve, climbing to the 24th place in science with the attainment of 471 mean scores which fell short of the 500 Centre point in TIMSS Scale (Martin et al., 2016).

Hence, Malaysia Education Blueprint 2013-2025 was a moment for Malaysia to explicitly declare (Ministry of Education, 2012) that they desire to attain the top third of the countries in international assessments such as ... TIMSS in [the next] 15 years to achieve a quality education (Ministry of Education, 2012, Executive Summary, p.9). To achieve its desire to be at the world top third, the Malaysian Ministry of Education has enumerated several concerns that may have play a part in the unfavorable achievement in TIMSS. Among these concerns is the unstableness of science teaching and learning quality in schools (Azian, 2015). Additionally, the science activities conducted in the classrooms were boring, non-captivating and uninteresting, mainly because there was "too much talking by their teachers" (Rohandi, 2017, p. 22), signifying a teacher-centered classroom with a prevalence of teacher talk. This echoes the previous findings by Ong and Ruthven (2010) who characterized the prevailing science teaching and learning in the Malaysian classrooms and found that it was mainly teacher-centered with didactic teaching and that note-copying syndrome was prevalent.

The analysis of the Malaysian science curriculum guides and syllabuses across grades and levels (Curriculum Development Division
[CDD], 2015, 2016, 2017) indicates that inquiry learning has been strongly advocated. For example, in the syllabus for third grade (CDD, 2017), a special theme on "Inquiry Learning" (pp. 37-52) has been specifically advocated. The emphasis on inquiry learning aims to cultivate the higherorder thinking skills (HOTS) among the children and HOTS are among the 21st Century skills as succinctly stated in the preface of the syllabuses, for example, "In ensuring the success of the Primary School Standard Curriculum, the teaching and learning of teachers should place emphases on Higher Order Thinking Skills by focusing on the Inquiry-based Learning approach so all required skills to survive in the 21 st century could be mastered by students" (CDD, 2017, p. ix). Such an emphasis on inquiry learning is in step with the direction of science education in other countries such as France, Denmark, the United Kingdom, and the European Union (Harlen, 2012).

There are many science pedagogical approaches to enacting inquiry-based teaching in the classrooms. Among these pedagogical approaches are Eggen and Kauchak's (2012) General Inquiry Model, Suchman's (1966) Inquiry Model, Llewellyn (2013)'s 6-Stage Inquiry Cycle, and Bybee and Landes's (1990) 5E Instructional Model which is alternatively termed as $5 \mathrm{E}$ Inquiry Learning Model (Ong et al., 2018) as it promotes inquiry in the learning of science (Duran \& Duran, 2004). The 5E Inquiry Learning Model, consisting of engagement, exploration, explanation, elaboration, and evaluation stages, was further expanded by Eisenkraft (2003) to that of $7 \mathrm{E}$ Inquiry Learning Model with the addition of the "elicitation" stage at the beginning, and the "extension" stage at the end.

The notion of inquiry learning, according to Ong et al. (2018), is still nebulous, ill-defined, and vague among the science teachers. Nebulous because the term "inquiry" is subjected to different interpretations and practices, it causes wi- 
despread confusion among the science teachers and the science teacher educators (Barrow, 2006). Therefore, it is unsurprising when Settlage (2003) reckons that the notion of "inquiry" is "... one of the most confounding terms within science education" (p. 34). Equally, Gautreau and Binns (2012) also noted the confusion among many science teachers as to the definition of inquiry, its implementation method, and the quality of its performance; above them all, there is a question why inquiry still remain uncommon inside classrooms nowadays (p. 169), signifying much less-than-expected enactment of inquiry-based teaching in the classrooms among the science teachers. Meanwhile, there is another fraction of teachers who are in their comfort zones of using one-way, didactic, transmission approach to the teaching of science (Kazempour \& Amirshokoohi, 2014; Lee, 1992; Ghani, 1988) despite the directive from the Ministry of Education to employ inquiry teaching and learning, specifically the $5 \mathrm{E}$ Inquiry Learning Model.

Because of these problematic situations, there is a need to provide teachers with the research-based classroom-validated examples of inquiry science teaching, particularly the $5 \mathrm{E}$ Inquiry Learning Model that has been advocated by the Malaysian Ministry of Education. This aims to familiarise the science teachers as to the definition of inquiry, its implementation method, and the quality of its performance (Gautreau \& Binns, 2012, p.169). Given that magnetism, according to Van Hook and Huziak-Clark (2007), is reckoned as an important topic in the study of natural science, and hence a rudimentary concept for pre-primary and primary school students (National Research Council [NRC], 1996), and that students almost interact daily with magnetic matters such as refrigerator magnets, magnetic blocks or magnetic toys, the topic on the magnet is thus chosen as the context of the study. Year 3 students are chosen for the study on the basis that the topic on the magnet is covered in the thirdgrade science syllabus (Curriculum Development Division, 2012).

Accordingly, the objective of this study is to determine the effect of the $5 \mathrm{E}$ Inquiry Learning Model on the science achievement of thirdgrade students' in learning magnet. Corollary, this study also tests the null hypothesis: There is no significant difference in the achievement in the learning of "Magnet" among third-grade Malaysian students who have followed through the $5 \mathrm{E}$ Inquiry Learning Model and the achievement in the learning of "Magnet" among the third-grade Malaysian students who have followed through the teacher-centered conventional teaching.

\section{E Inquiry Learning Model}

The Soviet Union successfully launched the world's first artificial satellite, Sputnik I on October 4, 1957, and this has ushered in new scientific, technological, political and military developments, particularly between the US and Russia. Lagging behind the Russians in space race has awakened the US to the extent that they started to re-look at the quality of their science curriculum and the science teaching in schools. Such a questioning contributed to a great shift in the goals of American Science Education, with mushrooming of many projects and initiatives, many of which are financially supported by the National Science Foundation (NSF).

Gagne (1963), in his seminal paper, proposed the over-arching purpose of science education that encompasses the sub-goals of students acquiring the attitudes, the methods, and the understanding of inquiry. He contended that students should be able to conduct inquiry just like the scientists and that the ability to be like the scientists is reliant on the attainment of the perceptive knowledge and scientific skills that include fundamental capabilities such as the skills of observing, classifying, inferring, hypothesizing, and conducting science investigations. He asserted that "an individual needs to know how to observe, to classify ... before he can understand science" (Gagne, 1963, p.152).

Equally, Schwab (1962) believed that students should understand the nature of science, comprehending the tentative nature of science whereby the currently acceptable science concepts may undergo revision in light of new information, evidence or discoveries. Additionally, Schwab (1960) had also advocated that science should be taught in an inquiry manner. Schwab (1960) categorized inquiry into stable inquiry and fluid inquiry. In a stable inquiry, the established principles determine the experiments, while in fluid inquiry, the established principles are reckoned as problems themselves. Accordingly, students need to be taught to construct bodies of evidence with the current theories and principles (i.e., stable inquiry) and to construct new theories and principles (i.e., fluid inquiry) through the judicious use of the laboratory work.

Hence, the prominent theme from the papers of Gagne (1963), Schwab (1960, 1962), and other reform documents such as the National Science Education Standards (National Research Council, 1996) and Project 2061: Science for All Americans (Rutherford \& Ahlgren, 1989) is the inclusion of inquiry-based teaching methodologies. Therefore, the 5E Inquiry Learning Model 
(Bybee \& Landes, 1990) will be discussed since it is the instructional method used in the study.

Bybee et al. (2006) established that " an effective, research-based instructional model, if continuously used, can guide students learn basic concepts in science and other domains" based on Bransford et al., (2000) How People Learn: Brain, Mind, Experience, and School and Donovan and Bransford's (2005) How Students Learn: Science in the Classroom. The consistent use of classroom-based and research-validated effective instructional models is crucial as it harnesses the effects on students' learning. Accordingly, the 5E Inquiry Learning Model is advocated in this study (Bybee \& Landes, 1990; Ong et al., 2018).

As acknowledged by Bybee et al. (2006), the $5 \mathrm{E}$ Inquiry Learning Model originates from the Three-Stage Learning Cycle propounded by Atkin \& Karplus (1962). The three stages are exploration, invention, and discovery. The exploration stage is characterized by providing students with the initial experience of the phenomenon at hand, while the invention stage is characterized by introducing students to new terms that are related to the concepts at hand. Meanwhile, the discovery stage is characterized by students applying concepts and using terms in new or novel situations. These three stages were subsequently being renamed and referred by Lawson $(1988 ; 1995)$ as exploration, term introduction, and concept application, and by Throwbridge \& Bybee (1990) as explore, explain, and expand.

The 5E Inquiry Learning Model (Bybee \& Landes, 1990) entails five stages: engagement, exploration, explanation, elaboration, and evaluation. There is a particular pedagogical function that underlies each of the five stages and together, these five stages constitute the inquiry learning process in the classroom. Nevertheless, the second, third, and fourth stages are generally similar to that of the three stages by Atkin and Kar- plus (1962). The pedagogical function for every stage in the 5E Inquiry Learning Model is summarized in Table 2. The enactment of 5E Inquiry Learning is illustrated using a third-grade primary science content with the learning outcomes in that students are expected to (i) generalize the action of a magnet on multiple objects by carrying out an investigation; (ii) classify objects based on the action of a magnet on them; (iii) state that objects made of iron are magnetic objects; and (iv) design an object based on the usage of a magnet.

In the first stage (i.e., engagement), a prediction worksheet that depicts a variety of objects is distributed and students are expected to predict whether or not each object is attracted by the magnet. Uncovering or eliciting students' existing ideas on objects which are attracted by a magnet is the main aim of the engagement stage. In the second stage (i.e., exploration), students are involved in hands-on science investigative activities within their respective cooperative learning groups to determine if their predictions are correct. They then discuss and record the observations. Providing similar hands-on science investigative activities for students to test their earlier predictions is the main aim of the exploration stage so that their initial, pre-existing ideas/knowledge could be plausibly restructured. In the third stage (i.e., explanation), the teacher uses students' common base hands-on experience to categorize the objects into two categories: objects that are attracted, and not attracted by magnet. The teacher then introduces the concept of magnetic objects. In the fourth stage (i.e., elaboration), students are tasked to plan, design and create a train carriage that capitalizes on the use of magnets within their respective cooperative learning groups. Finally, in the fifth stage (i.e., evaluation), students are administered a short quiz to determine the extent to which they have achieved the learning outcomes.

Table 2. Stages and Their Corresponding Pedagogical Functions in 5E Inquiry Learning Model

\begin{tabular}{|c|c|}
\hline Stage & Pedagogical Function \\
\hline Engagement & $\begin{array}{l}\text { The engagement stage aims to encourage students' curiosity and draw out } \\
\text { students' prior knowledge, so that they are engaged in, and thinking about, } \\
\text { the new concept by providing them with short activities. These activities as- } \\
\text { sist in making connections between the previous and present experiences of } \\
\text { learning, eliciting pre-instructional understanding, and organizing students' } \\
\text { post-instructional understanding from the learning activities. }\end{array}$ \\
\hline
\end{tabular}


Exploration The exploration stage provides students with similar or common activities /experiences so that conceptual change could be facilitated in which students' current or pre-instructional understanding and skills are meaningfully restructured. Students may conduct lab activities that help students to use pre-instructional understanding/views to explore questions, generate a hypothesis, and conduct a scientific investigation.

Explanation The explanation stage focuses students' attention on a particular aspect of the activities carried out during the engagement and exploration stages. It also provides opportunities for students to demonstrate their restructured views or understanding, process skills, or behaviors. Besides, teachers may also directly introduce a concept or skill. Students explicate and demonstrate their conceptual understanding. A teacher's explanation or the explanation given in the textbooks or curriculum should guide students towards a better and meaningful understanding.

Elaboration This stage is characterized by the applications and extension of the concepts learned and skills acquired through conducting new, novel or additional activities. The elaboration stage helps students to develop a thorough and meaningful understanding of the newly acquired concepts and skills.

Evaluation The stage assesses students' understanding and acquired skills. It also provides teachers with the opportunity to evaluate the extent to which their students have mastered or achieved the learning standards.

\footnotetext{
Abdi (2014) researched the effect of the 5E Inquiry Learning Model by Bybee et al. (2006) on the fifth-grade female students' science achievement in Kermanshah, Iran. The research was designed as the quasi-experimental, using pretestposttest and control group. Consisting of $20 \mathrm{fe}-$ male students each, two intact classes were assigned as the experimental and the control groups randomly.

The experimental group was "instructed with inquiry-based instruction supported $5 \mathrm{E}$ learning cycle" (Abdi, 2014, p. 39), while the traditional method was taught using the traditional method by the same teacher over an intervention period of 8 weeks. Three units were used as the context to the study, namely the microorganisms; nervous system; and human \& environment. The science achievement test consists of 30 teachermade multiple-choice items was administered as the pretest as well as the posttest. The test has internal consistency reliability with its Cronbach's alpha measuring at 0.75 and an appropriate content validity which was endorsed by two science teachers. The result from the Analysis of Covariance (ANCOVA) indicated a statistically significant difference, favoring the experimental group.

Meanwhile, Wilson et al. (2010) conducted a laboratory-based control study to gauge the effectiveness of the 5E Inquiry Learning Model on science achievement among 58 students aged 1416 years old. The true experimental design was employed when Wilson et al. (2010) randomly assigned students into one of two groups: experimental and control and both groups were taught
}

similar learning objectives by the same teacher. The experimental group was taught using the $5 \mathrm{E}$ Inquiry Learning Model, while the control group was taught using the teacher-centered conventional approach. The findings indicated that students in the experimental group achieved markedly higher than their peers in the control group. Hokkanen (2011), in her master's thesis, ascertained if the use of the 5E Learning Cycle Model could improve student science achievement, as compared to the commonplace method. There were 96, 98 and 114 7th grade students responded to the pre- and posttest for the respective three units of instruction: (i) atoms, (ii) force \& motion, and (iii) speed \& motion graphing. The experimental study lasted 3 weeks and the 57item Illinois State Achievement Test (ISAT) was used to measure the scientific achievement. The findings revealed that the students taught within $5 \mathrm{E}$ model obtain bigger advantages when the average percentage of development for each question was established and collected (Hokkanen, 2011).

It is summarized that the effectiveness of the $5 \mathrm{E}$ learning pattern was widely explored across different students' age (e.g., Abdi, 2014; Hokkanen, 2011; Wilson et al., 2010) in non-Malaysian contexts. The analysis from the literature review indicates that, while the effectiveness of $5 \mathrm{E}$ Inquiry Learning Model research in the nonMalaysian contexts are prevalent, such line of inquiry in the Malaysian context is still infrequent and hence the urgent need of such research to expand the repertoire of knowledge. 


\section{METHODS}

Based on the research question, the quasiexperiment pretest-posttest control group research design (Creswell, 2012) was deemed appropriate. Given the availability of two intact classes, each consisting of 20 students, one class was randomly assigned as the experimental group while another class as the control group. To maintain the ecosystem of the school with minimal disruption, intact classes were used. The second author taught both the experimental and control groups to evade any teacher effect. Table 3 summarizes the descriptive statistics of participating students.

Table 3. Descriptive Statistics of Participating Students

\begin{tabular}{|c|c|c|c|c|}
\hline & & \multicolumn{2}{|c|}{ Gender } & \multirow[b]{2}{*}{ Total } \\
\hline & & Male & Female & \\
\hline \multirow{3}{*}{ Group } & Control & 7 & 13 & 20 \\
\hline & Experiment & 9 & 11 & 20 \\
\hline & Total & 16 & 24 & 40 \\
\hline
\end{tabular}

Before the intervention, the teacher administered the pretest, and after the intervention, she administered the posttest. The posttest was similar to that of the pretest, and both comprised 12 multiple-choice items and 8 fill-in-the-blank items. Each multiple-choice item consists of one correct response and three distractors. Each of the 8 completion items requires students to give a correct response. Hence, all these items are marked dichotomously, either correct or incorrect. The developed items matched with the learning objectives identified in a test specification table. To enhance the content validity, the test items were examined by two science expert teachers. The test has sufficient internal consistency reliability measured by KR20 with a value of 0.62 (De Vaus, 2001; Nunnally, 1978).

To comply with the research ethics, the teacher (i.e., second author) sought permission from her headmaster to use her existing two intact science classes as research samples. A positive response was received from the headmaster, indicating that the research could be conducted. Upon the approval, the two classes were given the pretest six weeks before the intervention. The intervention lasted three 30 -minute periods, and the posttest was then administered. For the analysis of data, firstly, the pretest data would be analyzed using the independent samples t-test to establish the group equivalence in terms of initial student achievement (Creswell, 2012). If the result were not statistically significant which indicates that the two groups were equivalent in terms of initial achievement, the posttest data would then be analyzed using the independent samples t-test. However, if the analysis of pretest data was statistically significant, then the posttest data would be analyzed using ANCOVA (Analysis of Covariance) with the pretest data serving as a covariate.

\section{RESULTS AND DISCUSSION}

As shown in Table 4, the analysis of pretest data indicates that the pretest mean for the experimental group which had undergone the $5 \mathrm{E}$ inquiry learning was 12.90 , while the pretest mean for the control group was 11.60. Although there was a mean difference of 1.30 , the difference was not statistically significant $(\mathrm{t}=1.66, \mathrm{p}=.108>$ .05). Such a result implies that the initial difference in terms of science achievement between the groups was not statistically significant. Therefore, posttest data could be analyzed using an independent samples t-test given the equivalence of the two groups.

Table 4. Mean, Standard Deviation and Results of t-test for Pretest

\begin{tabular}{|c|c|c|c|c|c|c|c|c|}
\hline \multirow[t]{2}{*}{ Variable } & \multicolumn{3}{|c|}{ Experimental } & \multicolumn{5}{|c|}{ Control } \\
\hline & $\mathbf{N}$ & Mean & SD & $\mathbf{N}$ & Mean & SP & $\mathbf{t}$ & p \\
\hline Pretest & 20 & 12.90 & 3.11 & 20 & 11.60 & 1.60 & 1.66 & .108 \\
\hline
\end{tabular}


As shown in Table 5, the analysis of posttest data indicates that the posttest mean for the experimental group was 16.05 , while the posttest mean score for the conventional group was 13.15 . Statistically, the difference of 4.75 (p $=.000<.001)$ was real and significant. Therefore, the null hypothesis -- there was no statistical difference between the achievement in the learning of
"Magnet" among third-grade Malaysian students who have followed through the 5E Inquiry Learning Model and those who have followed through the conventional teacher-centered teaching -- was not accepted. This implies that the posttest difference between the two groups, favoring the experimental, was indeed a real difference and that it happened as the result of the intervention.

Table 5. Mean, Standard Deviation and Results of t-test for Posttest

\begin{tabular}{|c|c|c|c|c|c|c|c|c|}
\hline \multirow[t]{2}{*}{ Variable } & \multicolumn{3}{|c|}{ Experimental } & \multicolumn{5}{|c|}{ Control } \\
\hline & $\mathbf{N}$ & Mean & SD & $\mathbf{N}$ & Mean & $\mathbf{N}$ & $\mathbf{t}$ & $\mathbf{p}$ \\
\hline Posttest & 20 & 16.05 & 2.35 & 20 & 13.15 & 1.39 & 4.75 & .000 \\
\hline
\end{tabular}

The aim of this study is to determine the effect of the $5 \mathrm{E}$ Inquiry Learning Model as compared to the conventional method in enhancing third-grade students' science achievement using "magnet" as the learning material. The main finding of this study shows the positive and beneficial effect of using the $5 \mathrm{E}$ Inquiry Learning Model on students' achievement in the learning of "Magnet". Such a positive and beneficial effect is consistent with the previous findings although each of the studies measures the science achievement differently, and that diverse age groups were used.

In this study, a composite score deriving from the students' answers to the 12 multiplechoice and 8 fill-in-the-blank items was used to measure the science achievement. This may suggest that the present study failed to explore other important aspects of science achievement. In this era of the 21st Century, critical thinking, creative thinking, collaboration and communication which have been emphasized and famously considered together as the four C's, could the inquirybased science education enhance these four C's?

The $5 \mathrm{E}$ inquiry learning implemented in this study entails hands-on activities in the science room such as testing the predictions on whether or not an object is attracted by a magnet. In other words, the use of inquiry learning in this study takes the form of hands-on science investigative activities, and it affects students' science learning positively and beneficially. Using extrapolation, this research found corroboration of other positive and beneficial impacts of hands-on activities and student investigations on science learning (e.g., Shymansky et al., 1990; Klahr et al., 2007; Jaakkola \& Nurmi, 2008).

However, science teachers are facing many barriers that inhibit the integration of inquirybased science teaching in their classrooms that include "... the poverty of [science teachers'] common professional development experiences, $\ldots$ and definitions for what inquiry-based teaching is, and the lack of good resources enabling the capacity for change (Fitzgerald et al., 2019, p. 543). Barrow (2006) suggests that a consensus on the notion of inquiry should be reached to pave the way forward for the pedagogical courses at pre-service teacher education. Additionally, for science teachers and lecturers on the what, why and how of inquiry-based science teaching, the in-service professional development programs should be adequately provided (Akerson et al., 2007; Barrow, 2006; Akerson \& Hanuscin, 2007; Zohar, 2008; Silm et al., 2017).

In terms of in-service professional development (PD) programs, Ingvarson et al. (2005) have proposed five characteristics of effective PD in that it should focus on content, entail active learning, offer feedback, entail a collaborative examination of student work, and should involve long-term review. Content-wise, it should be on the various approaches and models of inquiry learning. Perhaps due to time constraints, we could concentrate on the 5E Inquiry Learning Model for a start. The PD should entail active learning where participants simulate through the 5E Inquiry Learning Model where they assume the role of a student while the facilitator acts as a teacher. Such simulative training is what we termed as modeling the model where the facilitator explicitly model for their participants the pedagogical thoughts and actions that underpin the stages in the 5E Inquiry Learning Model. To show the grasp of the 5E Inquiry Learning Model, the participants could plan a lesson around the use of the $5 \mathrm{E}$ Inquiry Learning Model and then carry out the plan either with their colleagues or other participants acting as students or with their real students in their respective schools. The facilita- 
tor or other senior teachers serving as mentors could observe and provide at-the-elbow support and immediate feedback. As for collaborative examination of student work, the participants could be brought together to asses student work and provide opportunities for feedback in the workplace, which requires an appropriate balance between upfront practice and backroom collegial analysis and reflection on practice in the light of standards for student learning and professional practice (Ingvarson et al., 2005). Such learning is a long term process.

Finally, the findings of this study were derived only from the third-grade Malaysian students in a particular school. As such, more studies investigating the similar impact of the $5 \mathrm{E}$ Inquiry Learning Model should be conducted by using more representative Malaysian third-grade students and perhaps be expanded across the primary years to establish a more valid generalization of its positive impact.

\section{CONCLUSION}

Based on the discussion in the preceding sections, it can be concluded that the use of the 5E Inquiry Learning Model is indeed successful in enhancing students' achievement in the learning of science. In other words, the science learning and teaching process through $5 \mathrm{E}$ Inquiry Learning Model are more effective as compared to the conventional model in enhancing the science achievement among primary students, particularly on the concept of a magnet. This positive effect on student achievement is attributed to the judicious employment and enactment of a teaching and learning process that truly and aptly integrates the 5E Inquiry Learning Model.

\section{ACKNOWLEDGMENT}

We would like to acknowledge and thank the Ministry of Education for the provision of the Research Grant [Coded as 2019-0029-107-02 (FRGS/1/2018/SSI09/UPSI/01/3)]. Equally, we would like to thank the participating students who were truly cooperative and marvelous.

\section{REFERENCES}

Abdi, A. (2014). The effect of inquiry-based learning method on students' academic achievement in science course. Universal Journal of Educational Research, 2(1), 37-41.

Akerson, V. L., Hanson, D. L., \& Cullen, T. A. (2007). The influence of guided inquiry and explicit instruction on K-6 teachers' views of nature of science. Journal of Science Teacher Education, 18(5), 751-772.

Akerson, V. L., \& Hanuscin, D. L. (2007). Teaching nature of science through inquiry: The results of a 3-year professional development program. Journal of Research in Science Teaching, 44(5), 653-680.

Atkin, J. M., \& R. Karplus. (1962). Discovery or invention?. The Science Teacher, 29(5), 45-51.

Azian, T.S.A. (2015). STEM Education: Policies and prospects towards achieving international standard and meeting national development needs. Keynote address given at Internationa Science, Technology, Engineering and Mathematics High-Level Policy Forum on Evidence-Based Science Education in Developing Countries, 26-27 May 2015, Istana Hotel, Kuala Lumpur.

Barrow, L. (2006). A brief history of inquiry: From Dewey to standards. Journal of Science Teacher Education, 17(3), 265-278.

Bransford, J.D., Brown, A.L., \& Cocking, R.R. (2000). How People Learn: Brain, Mind, Experience, and School. Washington, DC: National Academy Press.

Bybee, R., \& Landes, N.M. (1990). Science for life and living: An elementary school science program from Biological Sciences Improvement Study (BSCS). The American Biology Teacher, 52(2), 9298.

Bybee, R.W., Taylor, J.A., Gardner, A., Scotter, P. V., Powell, J. C., Westbrook, A., \& Landes, N. (2006) The BSCS 5E instructional model: Origins, effectiveness, and applications. Retrieved October 27, 2017 from http://www.bscs.org/pdf/bscs5eexecsummary.pdf

Campbell, D.T., \& Stanley, J.C. (1963). Experimental and quasi-experimental designs for research and teaching. In N.L. Gage (Ed.), Handbook of Research on Teaching (pp. 171-246). Chicago: Rand McNally.

Crawford, B. A. (2007). Learning to teach science as inquiry in the rough and tumble of practice. Journal of Research in Science Teaching, 44(4), 613-642.

Creswell, J.W. (2012). Educational research: Planning, conducting, and evaluating quantitative and qualitative research ( $4^{\text {th }}$ ed.). Upper Saddle River, NJ: Pearson.

Curriculum Development Division. (2012). Dokumen Standard Sekolah Rendah (DSKP): Dunia Sains dan Teknologi Tahun 3. Putrajaya: Ministry of Education Malaysia.

Curriculum Development Division. (2015). Kurikulum Standard Sekolah Rendah Sains Tahun 1: Dokumen Standard Kurikulum dan Pentaksiran. Putrajaya: Ministry of Education Malaysia.

Curriculum Development Division. (2016). Kurikulum Standard Sekolah Rendah Sains Tahun 2: Dokumen Standard Kurikulum dan Pentaksiran. Putrajaya: Ministry of Education Malaysia.

Curriculum Development Division. (2017). Kurikulum Standard Sekolah Rendah Sains Tahun 3: Doku- 
men Standard Kurikulum dan Pentaksiran. Putrajaya: Ministry of Education Malaysia.

De Vaus, D. A. (2001). Research Design in Social Research. London: SAGE.

Donovan, M.S., \& Bransford, J.D. (2005). How students learn: Science in the classroom. Washington, DC: National Academy Press.

Duran, L.B., \& Duran, E. (2004). The 5E Instructional Model: A learning cycle approach for inquirybased science teaching. The Science Education Review, 3(2), 49-58.

Educational Planning and Research Division. (2018). Quick Facts 2018: Malaysia Educational Statistics. Putrajaya: Ministry of Education Malaysia.

Eggen, P., \& Kauchak, D. (2012). Strategies and models for teachers: Teaching content and thinking skills $\left(6^{\text {th }}\right.$ ed.). New York: Pearson.

Eisenkraft, A. (2003). Expanding the 5E model. Science Teacher, 70(6), 56-59.

Fitzgerald, M., Danaia, L., \& McKinnon, D.H. (2019). Barriers inhibiting inquiry-based science teaching and potential solutions: Perceptions of positively inclined early adopters. Research in Science Education, 49(2), 543-566.

Gagne, R.M. (1963). The learning requirements for inquiry. Journal of Research in Science Teaching, 1(2), 144-153.

Gautreau, B.T., \& Binns, I.C. (2012). Investigating student attitudes and achievements in an environmental place-based inquiry in secondary classrooms. International Journal of Environmental \& Science Education, 7(2), 167-195.

Ghani, Z. (1988). Curricular decision-making in the diffusion of education innovation in Malaysia (Doctoral dissertation, University of Southampton).

Harlen, W. (2012). Inquiry in science education. Montrouge, France: Fondation La main à la pâte.

Hokkanen, S.L. (2011). Improving student achievement, interest and confidence in science through the implementation of the 5e learning cycle in the middle grades of an urban school. (Unpublished masters thesis). Montana State University, Bozeman, Montana, USA.

Ingvarson, L., Meiers, M., \& Beavis, A. (2005). Factors affecting the impact of professional development Educational Policy Analysis programs on teachers' knowledge, practice, student outcomes \& efficacy. Education Policy Analysis Archives, 13(10), 1-28.

Jaakkola, T., \& Nurmi, S. (2008). Fostering elementary school students' understanding of simple electricity by combining simulation and laboratory activities. Journal of Computer Assisted Learning, 24(4), 271-283.

Kazempour, M., \& Amirshokoohi, A. (2014). Transitioning to inquiry-based teaching: Exploring science teachers' professional development experiences. International Journal of Environmental \& Science Education, 9(3), 285-309.

Klahr, D., Triona, L. M., \& Williams, C. (2007). Hands on what? The relative effectiveness of physical versus virtual materials in an engineering de- sign project by middle school children. Journal of Research in Science Teaching, 44(1), 183-203.

Lawson, A.E. (1988). A better way to teach biology. American Biology Teacher, 50(5), 266-289.

Lawson, A.E. (1995). Science teaching and the development of thinking. Belmont, CA: Wadsworth.

Lee, M.N.N. (1992). School science curriculum reforms in Malaysia: World influences and national context. International Journal of Science Education, 14(3), 249-263.

Llewellyn, D. (2013). Teaching high school science through inquiry and argumentation. London: SAGE Publications Ltd.

Martin, M.O., Mullis, I.V.S., Foy, P., \& Stanco, G.M. (2012). The TIMSS 2011 International Results in Science. Chestnut Hill, MA: TIMSS \& PIRLS International Study Center, Boston College.

Martin, M.O., Mullis, I.V.S., Goy, P., \& Hooper, M. (2016). TIMSS 2015 International Results in Science. Boston: The International Association for the Evaluation of Educational Achievement (IEA).

Ministry of Education. (2012). Malaysia Education Blueprint 2013-2025 (Preschool to Post-secondary Education). Putrajaya: Ministry of Education Malaysia.

National Research Council (NRC). (1996). The National Science Education Standards. Washington: National Academy Press.

Nunnally, J. C. (1978). Psychometric Theory (2nd ed.). New York: McGraw Hill.

Ong, E.T., \& Ruthven, K. (2010). The distinctiveness and effectiveness of science teaching in the Malaysian 'Smart School'. Research in Science and Technological Education, 28(1), 25-41.

Ong, E.T., Arumugam, G., Sabri, M.S., Nor'ain, M.T., Nurulhuda, A.R., \& Mohamad Termizi, B. (2018). 5E Inquiry Learning Model: Its Effect on Science Achievement among Malaysian Year 5 Indian Students. International Journal of Academic Research in Business and Social Sciences, 8(12), 348-360.

Rohandi, R. (2017). Teaching and learning science: Students' perspective. International Journal of Indonesian Education and Teaching, 1(1), 16-31.

Rutherford, F. J., \& Ahlgren, A. (1989). Science for all Americans. New York: Oxford.

Schwab, J. (1960). Inquiry, the science teacher, and the educator. The School Review, 68(2), 176-195.

Schwab, J. J. (1962). The Teaching of Science. The Teaching of Science as Enquiry. [By] JJ Schwab. Elements in a Strategy for Teaching Science in the Elementary School.[By] Paul F. Brandwein. Harvard University Press.

Settlage, J. (2003, January). Inquiry's allure and illusion: Why it remains just beyond our reach. Paper presented at the annual meeting of the National Association for Research in Science Teaching, Philadelphia, PA.

Shymansky, J. A., Hedges, L. V., \& Woodworth, G. (1990). A reassessment of the effects of inquiry-based science curricula of the 60 's on stu- 
dent performance. Journal of Research in Science Teaching, 27(2), 127-144.

Suchman, J.R. (1966). Developing Inquiry. Chicago: Science Research Associates, Inc.

Throwbridge, L.W., \& Bybee, R.W. (1990). Becoming a secondary school science teacher. Columbus, Ohio: Merrill.

Van Hook, S., \& Huziak-Clark, T. (2007). Tip-to-tail: Developing a conceptual model of magnetism with kindergartners using inquiry-based instruction. Journal of Elementary Science Education, 19(2), 45-58.

Veloo, A., Perumal, S., \& Vikneswary, R. (2013). Inquiry-based instruction, students' attitudes and teachers' support towards science achievement in rural primary schools. 3rd World Conference on Learning, Teaching and Educational Leadership. Procedia - Social and Behavioral Sciences,
93, 65-69.

Wilson, C.D., Taylor, J. A., Kowalski, S.M., \& Carlson, J. (2010). The relative effects and equity of inquiry-based and commonplace science teaching on students' knowledge, reasoning, and argumentation. Journal of Research in Science Teaching, 47(3), 276-301.

Wu, H.K., \& Hsieh, C.E. (2006). Developing sixth grader's inquiry skills to construct explanations in inquiry-based learning environments. International Journal of Science Education, 28(11), $1290-1313$

Zohar, A. (2008). Science teacher education and professional development in argumentation. In S. Erduran \& M. P. Jimenez-Aleixandre (Eds.), Argumentation in science education: Perspectives from classroom-based research (pp. 245-268). Dordrecht, The Netherlands: Springer. 